\title{
FAKTOR-FAKTOR YANG MEMPENGARUHI NIAT MENGADOPSI USAHATANI SAYURAN ORGANIK DI KECAMATAN GETASAN SEMARANG
}

\author{
FACTORS AFFECTING THE INTENTION IN ADOPTING \\ ORGANIC VEGETABLES FARMING IN GETASAN SEMARANG \\ *Vaniamon Wira Yasyak, Suhatmini Hardyastuti, dan Slamet Hartono \\ Manajemen Agribisnis Fakultas Pertanian \\ Universitas Gadjah Mada
}

Submitted: 12-04-2019; Revised: 13-06-2019; Accepted: 17-05-2020

\begin{abstract}
Organic farming has attracted increasing attention in recent decades. Many believe this is necessary to maintain agricultural production while addressing environmental damages caused by conventional farming methods. However, the adoption of organic vegetable farming in Indonesia is still fairly slow. The fact that only a small number of farmers adopt organic farming begs explanation. Studies have shown that intention determines human behaviors. The problem is that intention to choose organic farming does not always manifest in behavior. To address this problem it is helpful to consider three factors affect how intention manifest in behavior, namely attitudes, subjective norms, and behavioral control. Based on in the case study on the central vegetable farming area of Kopeng village where conventional farming is still dominant, this paper analyzes the intention organic farmers in the light of the theory of planned behavior. Applying the SEM-PLS model of analysis, it identifies the key-driver organic farmers. This study found that farmers' positive attitude toward organic farming is not the main drive in their shift from non-organic to organic farming. Rather than subjective norms, behavior control has the greater influence on the farmers' choice to adopt organic vegetable farming. Famers view organic agriculture positively; but the main obstacle is the access to information about organics, certification capabilities and other aspects of behavioral control which make adoption rate for organic vegetable farming is still low.
\end{abstract}

Keywords: Adoption; Intention; Organic; SEM-PLS; Theory of Planned Bahaviour.

\begin{abstract}
ABSTRAK
Pertanian organik telah menarik perhatian yang meningkat dalam beberapa dekade terakhir sebagai sarana untuk mempertahankan produksi pertanian sambil mengatasi masalah lingkungan yang disebabkan oleh metode pertanian konvensional. Perkembangan dalam mengadopsi usahatani sayuran organik masih terbilang lambat di banyak daerah di Indonesia. Gejala bahwa sedikitnya petani yang mengadopsi pertanian organik perlu diidentifikasi lebih dalam. Perilaku tertentu yang dilakukan sering kali ditentukan oleh niat dari manusia. Niat seseorang terhadap perilaku tertentu dapat dibangun
\end{abstract}

*Corresponding author: vaniamonwirayasyak@gmail.com.

Copyright@ 2020 THE AUTHOR (S). This article is distributed under a Creative Commons Attribution-Share Alike 4.0 International license. Jurnal Kawistara is published by the Graduate School of Universitas Gadjah Mada. 
dari tiga faktor pendekatan theory of planned behaviour utama yaitu sikap, norma subjektif, dan kontrol perilaku. Niat petani perlu ditinjau untuk mengidentifikasi faktor pendorong utama untuk berniat mengadopsi usahatani sayuran organik. Penelitian ini dilakukan di daerah sentra sayuran Desa Kopeng, desa yang masih didominasi oleh pertanian konvensional. Analisis faktor dilakukan dengan Structural Equation Modelling - Partial Least Square (SEMPLS) untuk memprediksi key-driver dari model. Temuan penelitian cukup mengejutkan yaitu bahwa sikap positif terhadap usahatani sayuran organik tidak menjadi pendorong utama untuk berniat mengadopsi usahatani sayuran ke sistem organik. Justru dorongan norma subjektif akan memberikan pengaruh yang signifikan terhadap niat petani mengadopsi usahatani sayuran organik. Kontrol perilaku memiliki pengaruh paling besar dari faktor lain dalam penelitian di mana mempengaruhi niat petani mengadopsi usahatani sayuran organik. Pandangan terhadap pertanian organik telah terbentuk dan menyikapi baik mengenai organik. Akan tetapi hambatan utamanya adalah pada akses informasi mengenai pertanian organik, kemampuan mengikuti sertifikasi dan aspek kontrol perilaku lainnya juga menyebabkan tingkat adopsi usahatani sayuran organik masih rendah.

Kata kunci: Adopsi; Niat; Organik; SEM-PLS; Teori Perilaku Terencana.

\section{PENGANTAR}

Perkembangan pertanian dewasa ini tidak bisa dilepaskan dari revolusi hijau yang sejak tahun 1960-an telah digalakkan untuk meningkatkan produktivitas pertanian (Mayrowani, 2012)environmentally friendly life-style becomes a new trend and has been institutionalized internationally which requires assurance that agricultural products should be safe for consumption (food safety attributes. Pada prosesnya paket teknologi penggunaan benih unggul, pemanfaatan pupuk kimia, dan pestisida sintetis pengendali hama dianggap sebagai input pertanian yang paling efisien dan praktis. Tidak bisa dipungkiri, pembangunan prasarana pengairan, penelitian, pengembangan, dan permodalan serta subsidi sarana produksi pertanian telah meningkatkan produktifitas pertanian hingga mencapai surplus dan swasembada pangan. Pertanian konvensional mencapai peningkatan produktivitas melalui penggunaan bahan kimia dan pupuk. Akan tetapi, peningkatan produktivitas itu menjejakkan masalah baru di mana ekosistem tanah terdegradasi, struktur dan tekstur tanah pada musim kemarau menjadi lebih keras dan cepat kering, kelembaban tanah mudah berubah, munculnya jenis hama pengganggu yang kebal, dan kesehatan konsumen yang terjangkit oleh residu pestisida.

Fenomena perkembangan pertanian masa lampau itu telah mendorong kesadaran manusia bahwa usahatani tidak akan berkelanjutan apabila paket revolusi hijau ini tidak dikaji kembali. Banyak negara telah menyatakan minatnya dalam mempromosikan pertanian berkelanjutan, dan pertanian organik berada di garis depan gerakan pertanian berkelanjutan itu. Dalam hal ini, ada banyak penelitian yang mendukung peran pertanian organik di negara maju dan berkembang (Ayuya et al. 2015). Proses konversi ke usahatani organik tentunya mencerminkan perubahan perilaku di kalangan konsumen dan produsen atau petani. Karena meningkatnya kesadaran konsumen akan masalah kesehatan dan lingkungan, permintaan untuk makanan organik yang aman telah tumbuh secara signifikan di berbagai negara selama beberapa tahun terakhir dan ini menawarkan peluang bagi produsen dan eksportir negara berkembang untuk meningkatkan pendapatan dan kondisi hidup mereka (FiBL, 2016).

Kesadaran konsumen akan isu tentang pertanian organik semakin populer memasuki abad ke-21, ditandai dengan munculnya gaya hidup back to nature di kalangan masyarakat. Semakin tumbuhnya kesadaran masyarakat akan dampak buruk dari penggunaan bahan kimia pada input pertanian mendorong konsumen (terutama kalangan menengah ke atas) untuk beralih mengonsumsi makanan yang sehat dengan alasan untuk kesehatan dan lebih ramah lingkungan. Fenomena ini dapat berimplikasi semakin meningkatnya permintaan produk organik di masa mendatang. Sesuai dengan temuan Lapple dan 
Kelley (2010) bahwa berkembangnya produsen dan komoditas organik terjadi karena pengaruh gaya hidup masyarakat sebagai konsumen yang mulai memperhatikan pentingnya kesehatan dan lingkungan hidup dengan menggunakan produk organik yang tidak menggunakan bahan-bahan kimia sintetis buatan.

Sayangnya serapan hasil pertanian organic masih rendah. Hal ini menunut penjelasan mengapa tidak lebih banyak petani yang berpindah dari pertanian konvensional ke organik? Sejumlah penelitian telah berusaha untuk mendapatkan wawasan tentang proses adopsi pertanian organik dengan menggunakan teori ekonomi standar. Misalnya Pietola (2001) memperkirakan respons petani terhadap insentif ekonomi ketika mengonversi ke pertanian organik dan Kuminoff \& Wossink (2010) menerapkan pendekatan opsi nyata untuk menilai kompensasi yang diperlukan untuk mendorong konversi ke pertanian organik. Perspektif lainnya menggunakan pendekatan yang lebih luas dengan mempertimbangkan berbagai faktor sosioekonomi misalnya Läpple (2010). Karya-karya empiris ini menunjukkan bahwa harga output, perubahan kebijakan, faktor pertanian, dan struktural, karakteristik petani sendiri serta sistem informasi semuanya berkontribusi pada penyerapan pertanian organik. Meskipun memberikan pemahaman yang berharga tentang proses adopsi pertanian organik, semua studi ini tidak satu pun secara eksplisit menjelaskan kemauan dan kemampuan petani untuk beralih ke pertanian organik.

Gejala bahwa sedikitnya petani yang mengadopsi pertanian organik perlu dikaji lebih dalam. Perilaku tertentu yang dilakukan sering kali ditentukan oleh niat dari manusia. Niat seseorang terhadap perilaku tertentu dapat dibangun dari tiga faktor pendekatan theory of planned behaviour yaitu attitude toward behavior (sikap terhadap perilaku), subjective norms (norma subjektif), dan perceived behavioral control (persepsi kontrol perilaku) (Ajzen 2005). Niat dapat dilihat dari petani yang berada di salah satu sentra usahatani sayuran di Desa Kopeng, Kecamatan Getasan, Kabupaten Semarang, Jawa Tengah. Riset mengenai faktor yang mempengaruhi niat petani untuk mengadopsi usahatani sayuran organik diperlukan sebagai bahan masukan untuk manajemen sumberdaya manusia.

Seperti disebutkan sebelumnya bahwa di TPB faktor-faktor berupa sikap, norma subjektif, dan kontrol perilaku dapat diperoleh secara langsung atau berasal dari keyakinan petani yang menonjol. Keyakinan ini dapat dikombinasikan untuk membentuk agregat yang mengungkap mengapa orang memegang sikap tertentu, norma subjektif yang diikuti, dan kuatnya kontrol perilaku seseorang (Ajzen, 2005). Oleh karena itu, ketiga faktor tersebut kemudian diuraikan dengan menggabungkan keyakinan yang mendasarinya. Konstruk dari model penelitian dapat dilihat pada Gambar 1.

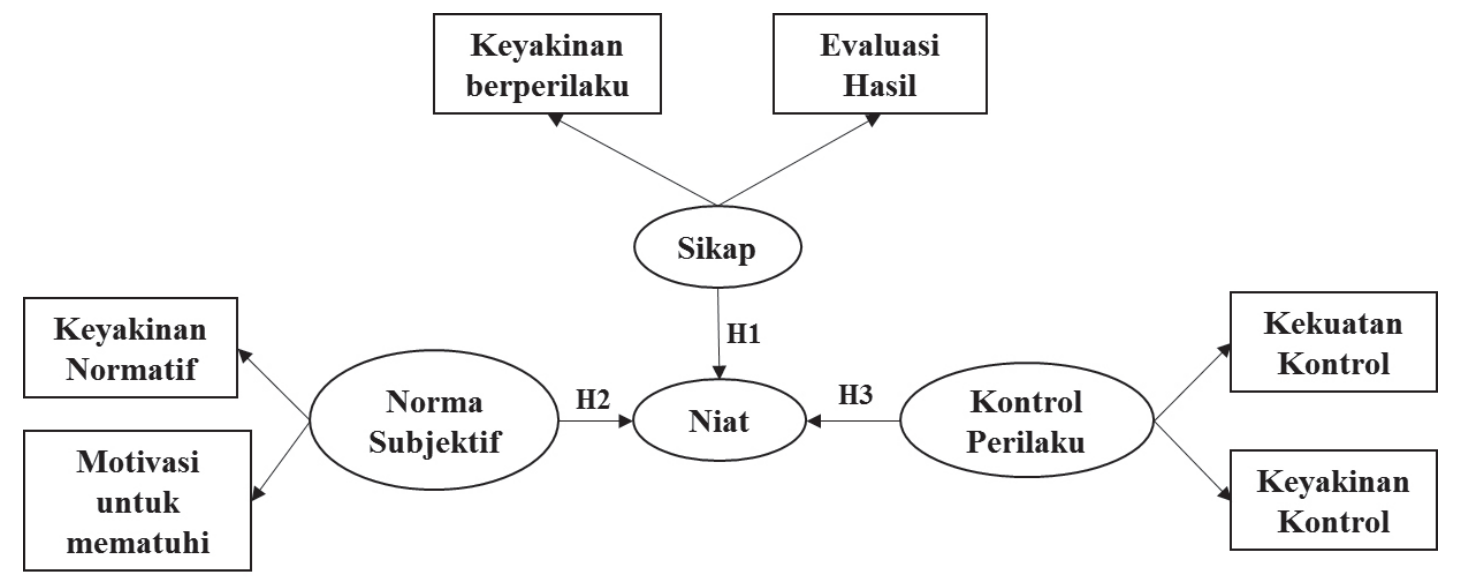

Gambar 1

Model Konstruksi Penelitian melalui Pendekatan Theory of Planned Behaviour 
Variabel sikap diartikan sebagai seberapa kuat penilaian positif atau negatif untuk mengadopsi usahatani sayuran organik. Variabel ini merupakan konstruk laten di mana diukur dengan menggunakan indikator keyakinan berperilaku yang berkaitan dengan keyakinan petani terhadap adanya konsekuensi manfaat jika mengadopsi usahatani sayuran organik. Keyakinan ini dapat memperkuat sikap terhadap perilaku yang positif apabila berdasarkan evaluasi hasil yang dilakukan, diperoleh data bahwa perilaku itu dapat memberikan keuntungan/manfaat baginya baik eksplisit maupun implisit. Evaluasi terhadap hasil merupakan evaluasi terhadap konsekuensi mengadopsi usahatani sayuran organik.

Variabel norma subjektif dalam penelitian ini didefinisikan sebagai persepsi terhadap pengaruh sosial yang akan menganjurkan agar mengadopsi usahatani sayuran organik. Sebagaimana sikap, norma subjektif juga dipengaruhi oleh keyakinan. Variabel norma subjektif adalah konstruk laten di mana diukur melalui indikator keyakinan normatif dan motivasi untuk mematuhi. Keyakinan normatif berkaitan dengan keyakinan petani yang diperoleh atas orang-orang dan lingkungan sekitar mengenai adopsi usahatani sayuran organik. Sedangkan motivasi untuk mematuhi adalah motivasi petani mematuhi orang-orang dan lingkungan sekitar untuk mengadopsi usahatani sayuran organik.

Kontrol perilaku dalam penelitian ini didefinisikan sebagai persepsi yang dirasakan tentang kemampuan dan sumberdaya yang dimilikinya untuk dapat mewujudkan usahatani sayuran organik. Kontrol perilaku sebagai variabel laten konstruk diukur dengan indikator keyakinan kontrol dan kekuatan kontrol. Keyakinan kontrol adalah keyakinan akan faktor/sumberdaya yang dapat mendorong atau menghambat niat mengadopsi usahatani sayuran organik. Kekuatan kontrol adalah persepsi petani mengenai seberapa besar peran sumberdaya/ faktor yang mendorong atau menghambat niat mengadopsi usahatani sayuran organik.
Pemilihan lokasi penelitian ditentukan secara purposive, yang merupakan suatu kesengajaan memilih lokasi, yaitu di Desa Kopeng Kecamatan Getasan, yang merupakan salah satu sentra pertanian komoditas sayuran di Kabupaten Semarang. Desa Kopeng memiliki potensi mengadopsi pertanian organik karena kebijakan pemerintah setempat sangat terbuka untuk pengembangan pertanian berkelanjutan, serta sudah ada desa (Desa Batur) yang telah berusahatani sayuran organik di mana ada asumsi bahwa Desa Kopeng telah mengetahui tentang sayuran organik dan ada pengaruh sosial ekonomi dari Desa Batur mengenai sayuran organik. Penelitian ini dilakukan selama dua bulan dari November sampai Desember 2019.

Penentuan ukuran sampel sesuai dengan rekomendasi Cohen (1992) dalam Hair (2014)by Hair, Hult, Ringle, and Sarstedt, provides a concise yet very practical guide to understanding and using PLS structural equation modeling (PLS-SEM dengan statistical power level sebesar $80 \%$, untuk mendeteksi minimal nilai $\mathrm{R}^{2}$ sebesar 0,25 dengan tingkat kesalahan 5\%, dan jumlah maksimum jalur struktural terbesar sebanyak 3, maka jumlah sampel yang dibutuhkan peneliti adalah 60 sampel responden. Populasi dari penelitian ini adalah petani pemilik penggarap yang berusahatani sayuran anorganik. Pengambilan sampel dilakukan dengan cara proportional random sampling, di mana sampel dikelompokkan menurut karakteristik geografis dusun kemudian secara random dan proporsional ditetapkan anggota sampelnya.

Pengumpulan data dilakukan dengan cara wawancara melalui pengajuan pertanyaan yang telah disusun sebelumnya di mana diadopsi dari Borges (2014) dan Issa dan Hamm (2017)the organic sector in Syria is comparatively young and only a very small area of FFV is organically managed. To date, little is known about Syrian farmers' attitudes towards organic FFV production. Therefore, the aim of this study was to explore the intentions and attitudes of Syrian farmers of FFV towards organic farming and how likely they are to convert their farms to organic production 
within the next five years. Using a two-stage cluster sampling procedure, 266 conventional farmers of FFV in 75 villages located in different districts of Syria's coastal region were selected for this survey. Data was collected through face-to-face interviews by a project partner in Syria (Citrus Fruit Board in Tartous, yang ditujukan kepada responden terpilih. Metode analisis data menggunakan Structural Equation Modelling (SEM) untuk analisis relasi causeeffect diantara konstruk model secara Partial Least Squares atau yang lebih dikenal dengan SEM-PLS (Hair, 2014) by Hair, Hult, Ringle, and Sarstedt, provides a concise yet very practical guide to understanding and using PLS structural equation modeling (PLS-SEM.

\section{PEMBAHASAN}

Berdasarkan tabel satu mayoritas responden menunjukkan kecenderungan sikap yang baik dan menilai secara positif usahatani sayuran organik dengan rata-rata 60,6\% menjawab setuju dan sangat setuju. Sikap didasari oleh keyakinan dan evaluasi hasil di mana diuraikan dalam beberapa indikator.

Tabel 1

Frekuensi Variabel Sikap terhadap Usahatani Sayuran Organik

\begin{tabular}{|c|c|c|c|c|c|c|}
\hline \multirow[t]{2}{*}{ Kode } & \multirow[t]{2}{*}{ Indikator } & \multicolumn{5}{|c|}{$\begin{array}{c}\text { Persentase Jawaban } \\
\text { Responden }(\%)\end{array}$} \\
\hline & & STS & TS & $\mathbf{N}$ & $\mathrm{S}$ & SS \\
\hline \multicolumn{7}{|c|}{ Keyakinan berperilaku (Behaviourial belief) } \\
\hline bs1 & Menghemat rata-rata biaya produksi & 1,7 & 13,3 & 40,0 & 35,0 & 10,0 \\
\hline bs2 & Menerima harga jual yang lebih tinggi & 1,7 & 13,3 & 38,3 & 38,3 & 8,3 \\
\hline bs3 & Meningkatkan pendapatan usahatani & 1,7 & 11,7 & 46,7 & 31,7 & 8,3 \\
\hline bs4 & Mendapatkan peluang pasar lain & 1,7 & 8,3 & 41,7 & 40,0 & 8,3 \\
\hline bs5 & Organik bukan cara bertani modern & 3,3 & 10,0 & 38,3 & 35,0 & 13,3 \\
\hline bs6 & Meningkatkan kesuburan tanah dan menjaga struktur tanah & 0,0 & 3,3 & 26,7 & 38,3 & 31,7 \\
\hline bs7 & Melindungi lingkungan & 0,0 & 5,0 & 40,0 & 30,0 & 25,0 \\
\hline bs8 & Menyediakan makanan sehat untuk keluarga saya & 0,0 & 5,0 & 46,7 & 35,0 & 13,3 \\
\hline bs9 & Berisiko bila mengkonversi ke sayuran organik & 0,0 & 5,0 & 43,3 & 41,7 & 10,0 \\
\hline \multicolumn{7}{|c|}{ Evaluasi Hasil (Outcome Evaluation) } \\
\hline oe1 & Penting menghemat biaya produksi & 0,0 & 0,0 & 18,3 & 41,7 & 40,0 \\
\hline oe2 & Penting menerima harga jual yang lebih tinggi & 0,0 & 1,7 & 16,7 & 38,3 & 43,3 \\
\hline oe3 & Penting meningkatkan pendapatan usahatani & 0,0 & 1,7 & 18,3 & 35,0 & 45,0 \\
\hline oe4 & Penting mendapatkan peluang pasar yang lebih baik & 0,0 & 0,0 & 25,0 & 33,3 & 41,7 \\
\hline oe5 & Penting menjadikan usahatani yang modern & 0,0 & 3,3 & 28,3 & 38,3 & 30,0 \\
\hline oe6 & Penting meningkatkan kesuburan tanah dan struktur tanah & 0,0 & 0,0 & 21,7 & 35,0 & 43,3 \\
\hline oe7 & Penting melindungi lingkungan & 0,0 & 1,7 & 36,7 & 25,0 & 36,7 \\
\hline oe8 & Penting menyediakan makanan sehat untuk keluarga & 0,0 & 6,7 & 38,3 & 30,0 & 25,0 \\
\hline \multirow[t]{2}{*}{ oe9 } & Penting berusahatani dengan aman & 0,0 & 6,7 & 38,3 & 28,3 & 26,7 \\
\hline & Rata-rata $(\%)$ & 0,6 & 5,4 & 33,5 & 35,0 & 25,6 \\
\hline
\end{tabular}

* STS (sangat tidak setuju); TS (Tidak Setuju); N (Netral); S (Setuju); SS (Sangat Setuju) Sumber: Analisis Data Primer 2018

Sebesar $70 \%$ responden paling utama meyakini usahatani sayuran organik meningkatkan kesuburan tanah dan struktur tanah. Indikator selanjutnya yang cenderung positif adalah praktik usahatani sayuran organik dapat melindungi lingkungan dari pencemaran akibat penggunaan pupuk dan pestisida kimia. Hal ini menunjukkan keyakinan 
responden yang menganggap bahwa usahatani sayuran organik menawarkan penyelesaian masalah lingkungan.Walaupun indikator lain yang mewakili aspek sosial ekonomi juga cenderung mengarah positif seperti praktek usahatani sayuran organik akan menghemat rata rata biaya produksi, menerima harga jual yang lebih tinggi, mendapatkan peluang pasar yang lebih luas dan menyediakan makanan sehat untuk keluarga. Tabel satu juga menunjukkan indikator yang dinilai menjadi prioritas utama yang diharapkan di mana digambarkan pada dimensi evaluasi hasil. Sebesar $81,7 \%$ responden cenderung memprioritaskan pentingnya menghemat/ mengurangi rata-rata biaya produksi usahatani. Kemudian diikuti indikator aspek ekonomi lainnya, akan pentingnya menerima harga jual yang lebih tinggi dan meningkatkan pendapatan usahatani. Artinya terlihat bahwa sikap responden memandang usahatani sayuran organik adalah suatu yang baik karena diyakini menawarkan penyelesaian masalah mengenai lingkungan seperti kondisi tanah, pencemaran udara, produk bebas bahaya bahan kimia. Akan tetapi, lebih memprioritaskan pentingnya aspek ekonomi dapat diperoleh terlebih dahulu.

Norma subjektif adalah persepsi terhadap pengaruh norma sosial yang akan menganjurkan memproduksi sayuran organik atau tidak. (Icek Ajzen, 2005) menjelaskan bahwa norma subjektif dapat direfleksikan dari keyakinan normatif dan motivasi untuk mematuhi. Tabel dua menunjukkan kecenderungan keyakinan normatif dan motivasi untuk mematuhi yang mencerminkan norma subjektif mengenai usahatani sayuran organik.

Tabel 2

Frekuensi Variabel Norma Subjektif

\begin{tabular}{|c|c|c|c|c|c|c|}
\hline \multirow{2}{*}{ Kode } & \multirow{2}{*}{ Indikator } & \multicolumn{5}{|c|}{ Persentase Jawaban Responden (\%) } \\
\hline & & STS & TS & $\mathbf{R R}$ & $\mathrm{S}$ & SS \\
\hline \multicolumn{7}{|c|}{ Keyakinan Normatif (Normative belief) } \\
\hline $\mathrm{nb1}$ & Keluarga menganjurkan berusahatani sayuran organik & 3,3 & 28,3 & 48,3 & 18,3 & 1,7 \\
\hline $\mathrm{nb2}$ & Rekan sesama petani menganjurkan & 1,7 & 13,3 & 51,7 & 26,7 & 6,7 \\
\hline nb3 & Pemodal/pelaku bisnis menganjurkan & 0,0 & 11,7 & 41,7 & 36,7 & 10,0 \\
\hline $\mathrm{nb} 4$ & Pemerintah menganjurkan & 1,7 & 15,0 & 61,7 & 20,0 & 1,7 \\
\hline nb5 & Media sosial menganjurkan & 5,0 & 15,0 & 71,7 & 6,7 & 1,7 \\
\hline \multicolumn{7}{|c|}{ Motivasi Untuk Mematuhi (Motivation to comply) } \\
\hline mc1 & Ingin mengikuti anjuran keluarga & 3,3 & 23,3 & 46,7 & 23,3 & 3,3 \\
\hline mc2 & Ingin mengikuti anjuran rekan sesama petani & 0,0 & 6,7 & 20,0 & 33,3 & 40,0 \\
\hline mc3 & Ingin mengikuti anjuran pemodal/pelaku bisnis & 0,0 & 3,3 & 25,0 & 36,7 & 35,0 \\
\hline mc4 & Ingin mengikuti anjuran pemerintah & 1,7 & 8,3 & 40,0 & 36,7 & 13,3 \\
\hline ma5 & Ingin mengikuti anjuran media sosial & 5,0 & 6,7 & 51,7 & 21,7 & 15,0 \\
\hline \multicolumn{2}{|c|}{ Rata rata (\%) } & 2,2 & 13,2 & 45,9 & 26,0 & 12,8 \\
\hline
\end{tabular}

* STS (sangat tidak setuju); TS (Tidak Setuju); N (Netral); S (Setuju); SS (Sangat Setuju) Sumber : Analisis Data Primer 2018

Berdasarkan tabel 2 tampak bahwa mayoritas responden cenderung belum optimal dalam merespon norma subjektif atau pengaruh sosial yang ditunjukkan dengan rata-rata sebesar $45,9 \%$ menjawab netral atau tidak mengarah menolak atau menerima secara utuh dukungan dari pihak tertentu. Namun keyakinan normatif dari pemodal atau pebisnis lebih cenderung lebih besar memberi dukungan agar mengadopsi usahatani sayuran organik daripada pihak yang lainnya. Model agribisnis kemitraan sering terjadi akibat pengaruh sosial 
dari pebisnis dan pemodal. Meskipun belum sepenuhnya organik, petani dianjurkan untuk mengurangi pemakaian input produksi yang tidak ramah lingkungan di mana anjuran ini berasal dari mitra bisnis.

Pada dimensi motivasi untuk mematuhi, sebagian besar responden ingin melakukan apa yang dianjurkan rekan sesama petani, pemodal/pebisnis kemitraan, dan pemerintah. Hal ini ditandai dengan ratarata responden cenderung menjawab setuju dan sangat setuju. Keluarga dan sosial media rendah dalam mengintervensi petani agar berusahatani organik. Pemodal dan pebisnis bukan hanya berperan sebagai investor, tetapi turut berempati serta menghadapi risiko bisnis yang terjadi selama bermitra dengan petani. Sehingga sering ditemukan kemitraan antara petani dan pemodal. Pengembangan bibit, pupuk, rantai pasok input pertanian, dan rantai pemasaran sering menjadi fokus dalam peningkatan kinerja usahatani. Rekan sesama petani juga akan menjadi subjek normatif yang berperan memberikan pengaruh dukungan sosial mengenai adopsi usahatani sayuran organik. Petani mulai membentuk kelompok tani yang memiliki orientasi untuk perlahan diubah menjadi sistem organik. Dusun Plalar di Desa Kopeng salah satunya terdapat perkumpulan petani yang mencoba mengurangi pemakaian pupuk dan pestisida kimia. Rekan sesama petani memang cukup baik untuk meyakinkan petani lainnya untuk mengadopsi usahatani organik.

Kontrol perilaku untuk mengadopsi usahatani sayuran organik sesuai dengan sumber daya yang dimiliki diuraikan dari keyakinan dan kekuatan kontrol. Tabel 3 menunjukkan frekuensi kecenderungan jawaban responden mengenai kontrol perilaku untuk mengadopsi usahatani sayuran organik. Pada umumnya responden masih meragukan kekuatan kendali mereka untuk berusahatani sayuran organik, hanya sebesar 48,3\% responden cenderung memiliki kontrol atau kendali dalam menggunakan pupuk organik tanpa adanya campuran kimia. Dari sisi lain, setiap elemen kontrol perilaku tersebut disadari kuat peranannya untuk dimiliki di mana tercermin pada indikator kekuatan kontrol yang cenderung menjawab setuju dan sangat setuju.

Tabel 3

Frekuensi Variabel Kontrol Perilaku

\begin{tabular}{|c|c|c|c|c|c|c|}
\hline \multirow[t]{2}{*}{ Kode } & \multirow[t]{2}{*}{ Indikator } & \multicolumn{5}{|c|}{$\begin{array}{c}\text { Persentase Jawaban } \\
\text { Responden }(\%)\end{array}$} \\
\hline & & STS & TS & $\mathbf{R R}$ & $\mathrm{S}$ & SS \\
\hline \multicolumn{7}{|c|}{ Keyakinan kontrol } \\
\hline $\mathrm{cb} 1$ & Mampu mengakses informasi tentang usahatani sayuran organik & 5,0 & 18,3 & 53,3 & 23,3 & 0,0 \\
\hline $\mathrm{cb} 2$ & Kesuburan tanah sangat cocok & 6,7 & 20,0 & 43,3 & 28,3 & 1,7 \\
\hline cb3 & Ketersediaan lahan untuk organik & 5,0 & 20,0 & 48,3 & 23,3 & 3,3 \\
\hline $\mathrm{cb} 4$ & Mampu menggunakan pupuk organik tanpa kimia & 0,0 & 13,3 & 38,3 & 35,0 & 13,3 \\
\hline cb5 & Mampu membayar sertifikasi dan inspeksi organik & 3,3 & 41,7 & 43,3 & 11,7 & 0,0 \\
\hline $\mathrm{cb} 6$ & Memiliki akses kredit & 3,3 & 41,7 & 43,3 & 10,0 & 1,7 \\
\hline $\mathrm{cb} 7$ & Memiliki akses subsidi pemerintah & 3,3 & 43,3 & 40,0 & 13,3 & 0,0 \\
\hline $\mathrm{cb} 8$ & Kolektivitas antar petani dalam masalah pertanian & 1,7 & 16,7 & 50,0 & 25,0 & 6,7 \\
\hline \multicolumn{7}{|c|}{ Kekuatan kontrol } \\
\hline pc1 & Akses informasi memudahkan berusahatani sayuran organik & 0,0 & 1,7 & 30,0 & 35,0 & 33,3 \\
\hline pc2 & Tanah yang subur memudahkan berusahatani sayuran organik & 0,0 & 5,0 & 21,7 & 33,3 & 40,0 \\
\hline pc3 & Ketersediaan lahan memudahkan berusahatani sayuran organik & 1,7 & 5,0 & 23,3 & 35,0 & 35,0 \\
\hline pc4 & Mampu menggunakan pupuk organik memudahkan & 1,7 & 5,0 & 15,0 & 38,3 & 40,0 \\
\hline
\end{tabular}




\begin{tabular}{|c|c|c|c|c|c|c|}
\hline \multirow[t]{2}{*}{ Kode } & \multirow[t]{2}{*}{ Indikator } & \multicolumn{5}{|c|}{$\begin{array}{c}\text { Persentase Jawaban } \\
\text { Responden }(\%)\end{array}$} \\
\hline & & STS & TS & RR & $\mathrm{S}$ & SS \\
\hline pc5 & $\begin{array}{l}\text { Mampu membayar sertifikasi dan inspeksi organik } \\
\text { memudahkan }\end{array}$ & 0,0 & 8,3 & 23,3 & 38,3 & 30,0 \\
\hline pc6 & Memiliki akses ke kredit memudahkan & 0,0 & 5,0 & 30,0 & 33,3 & 31,7 \\
\hline pc7 & Memiliki akses ke subsidi pemerintah memudahkan & 0,0 & 8,3 & 25,0 & 28,3 & 38,3 \\
\hline pc8 & Kolektivitas antar petani memudahkan & 0,0 & 6,7 & 26,7 & 35,0 & 31,7 \\
\hline \multicolumn{2}{|c|}{ Rata-rata $(\%)$} & 2,0 & 16,3 & 34,7 & 27,9 & 19,2 \\
\hline
\end{tabular}

* STS (sangat tidak setuju); TS (Tidak Setuju); N (Netral); S (Setuju); SS (Sangat Setuju) Sumber : Analisis Data Primer 2018

Kurangnya kontrol perilaku untuk berusahatani organik dapat ditandai dengan sebagian besar responden cenderung menjawab sangat tidak setuju dan tidak setuju yang mengartikan belum memiliki akses kesubsidi pemerintah, akses kredit, dan mampu membayar sertifikasi. Responden juga masih meragukan kesanggupan/kontrol mereka mengenai kemampuan akses informasi organik, apakah kesuburan lahan cocok, ketersediaan lahan untuk organik dan kolektivitas dengan petani lain masih belum meyakinkan untuk menghadapi konversi ke usahatani sayuran organik.

Niat sering didefinisikan sebagai indikasi seberapa keras individu atas kesediaannya mencoba, bertindak, dan seberapa besar usaha mereka merencanakan untuk menjalankan suatu perilaku. Pada penelitian ini variabel niat dicerminkan dari beberapa pernyataan yang menunjukkan seberapa besar kecenderungan niat untuk mengadopsi usahatani sayuran organik.

Tabel 4

Frekuensi Variabel Niat

\begin{tabular}{l|l|c|c|c|c|c}
\hline \multirow{2}{*}{ Kode } & \multicolumn{1}{c|}{ Indikator } & \multicolumn{5}{c}{$\begin{array}{c}\text { Persentase Jawaban } \\
\text { Responden (\%) }\end{array}$} \\
\cline { 3 - 7 } & & STS & TS & RR & S & SS \\
\hline BI1 & $\begin{array}{l}\text { Berniat untuk mengadopsi usahatani sayuran organik dalam } \\
\text { lima tahun ke depan }\end{array}$ & 1,7 & 16,7 & 43,3 & 28,3 & 10,0 \\
\hline BI2 & Mengurangi pemakaian pupuk kimia dalam waktu dekat & 3,3 & 25,0 & 38,3 & 23,3 & 10,0 \\
\hline BI3 & $\begin{array}{l}\text { Mengeksplorasi informasi tentang usahatani sayuran } \\
\text { organik }\end{array}$ & 3,3 & 18,3 & 50,0 & 23,3 & 5,0 \\
\hline BI4 & Mengajak orang lain untuk berusahatani sayuran organik & 3,3 & 21,7 & 43,3 & 18,3 & 13,3 \\
\hline Rata-rata (\%) & 2,9 & 20,4 & 43,7 & 23,3 & 9,6 \\
\hline
\end{tabular}

* STS (sangat tidak setuju); TS (Tidak Setuju); N (Netral); S (Setuju); SS (Sangat Setuju)

Sumber : Analisis Data Primer 2018

Tabel 4 menunjukkan uraian yang mencerminkan niat untuk mengadopsi usahatani sayuran organik. Mayoritas petani masih ragu dalam menentukan bagaimana niat untuk mengadopsi usahatani sayuran organik. Dengan kata lain, petani masih belum bisa mematangkan keputusan dalam merencanakan akan adopsi. Sebagian lain petani juga menunjukkan niat yang kuat untuk mengadopsi usahatani sayuran organik. Akan tetapi, yang menjadi fokus adalah mayoritas petani masih ragu dalam niat. Hasil penelitian dapat menjadi landasan awal bahwa niat petani dapat saja berubah sewaktu waktu jika 
ada kendali eksternal yang mengubah dan mempengaruhiuntuk berusahatani sayuran organik.

Indikator niat juga dicerminkan dari mayoritas responden yang condong bersikap netral dalam kegiatan mengurangi pemakaian pupuk kimia. Dengan kata lain, petani masih menggunakan pupuk kimia dan pupuk kandang (organik) dengan maksud mengurangi biaya produksi. Akan tetapi, tingkat pemakaian pupuk kimia masih terus digunakan dan intensitas pengurangan pupuk kimia masih diusahakan secara normal. Sementara, niat adopsi juga masih diragukan dengan indikator yang mencerminkan tingkat ekplorasi informasi petani masih belum maksimal. Petani mengeksplorasi informasi usahatani dari sumber manapun namun tidak menekankan pada pencarian informasi usahatani sayuran organik. Selain itu, mayoritas petani masih ragu untuk mengajak orang lain berusahatani sayuran organik. Hal yang wajar karena adopsi usahatani sayuran organik masih dianggap wacana yang belum kuat untuk bisa direncanakan. Oleh karena itu, potensi niat yang kuat dapat terjadi ketika indikator niat juga semakin kuat.

Ada kemungkinan responden menerima usahatani sayuran organik dalam lima tahun ke depan. Jika tindakan mengurangi pemakaian pupuk kimia digalakkan untuk secara bertahap mengembalikan kesuburan tanah yang bebas dari paparan kimia. Ini adalah salah satu paket dari sistem pertanian organik perlu diterapkan di mana mencerminkan niat untuk mengadopsi usahatani sayuran organik yang kuat. Sementara, petani perlu juga berusaha selalu mengeksplorasi informasi seputar sistem produksi, sertifikasi, dan pemasaran mengenai sistem keseluruhan dari pertanian organik. Selanjutnya, niat untuk mengadopsi usahatani sayuran organik akan meningkat seiring dengan mengajak orang lain untuk berusahatani sayuran organik.

Pada evaluasi model pengukuran terdapat beberapa uji yang dilakukan yaitu uji validitas konvergen, validitas diskriminan, dan Average Varian Extract (AVE). sedangkan untuk mengukur reliabilitas digunakan dengan menilai cronbach alpha dan composite reliability.

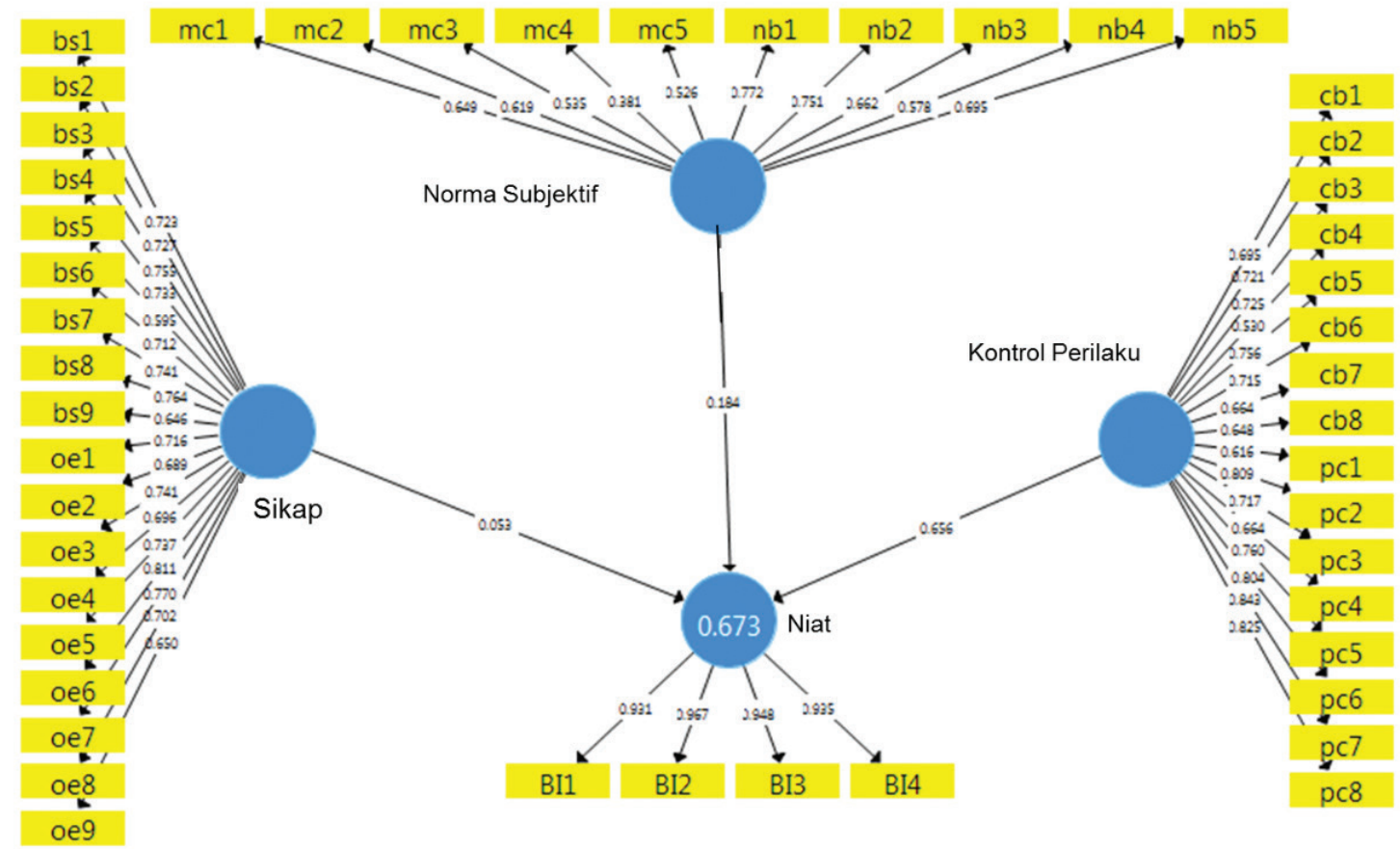

Gambar 2

Diagram Jalur Penelitian Sebelum Evaluasi Sumber: Analisis Data Primer 2018 
Adapun tujuanutama dilakukan evaluasimodel pengukuran adalah untuk menilai validitas dan reliabilitas model atau secara tidak langsung untuk menilai bahwa variabel indikator benarbenar mengukur variabel laten dalam model. Pengujian validitas dan reliabilitas dalam model reflektif dilakukan dalam tiga pengujian yaitu convergent validity, discriminant validity, composite reliability. Gambar dua menunjukkan hasil algoritma PLS dari model struktural penelitian sebelum dievaluasi. Hasil algoritma PLS berupa diagram jalur menampilkan nilai outer loading, path coefficient, dan nilai regresi. Untuk mengevaluasi validitas diagram jalur, jika outer loading kecil dari 0,4 maka indikator harus dihapus, jika outer loading berkisar antara 0,4-0,7, maka perlu dipertimbangkan dengan melihat AVE dan composite reliability, jika lebih besar dari 0,7 pertahankan indikator, disebabkan nilai AVE variabel dukungan yang masih $<0,5$, maka terdapat empat indikator yang harus dieliminasi dari diagram jalur yaitu indikator mc3, mc4, mc5, nb4 untuk mendapatkan nilai AVE yang baik.

Berdasarkan tabel 5 diketahui bahwa nilai AVE semua variabel eksogen dan endogen bernilai lebih dari 0,5 sesudah evaluasi. Validitas konvergen memenuhi syarat jika nilai AVE lebih besar dari 0,5. Berdasarkan hasil tersebut maka syarat validitas konvergen terpenuhi yang berrati semua indikator berkorelasi dengan variabel latennya masing masing atau memiliki validitas konvergen.

Tabel 5

Hasil Evaluasi Validitas dan Reliabilitas

\begin{tabular}{l|l|l|l}
\hline & Cronbach's Alpha & Composite Reliability & Average Variance Extracted (AVE) \\
\hline Sebelum evaluasi & \multicolumn{1}{l}{} \\
\hline Niat & 0,960 & 0,971 & 0,894 \\
\hline Sikap & 0,945 & 0,950 & 0,517 \\
\hline Norma Subjektif & 0,828 & 0,862 & 0,393 (tidak valid) \\
\hline Kontrol Perilaku & 0,938 & 0,945 & 0,522 \\
\hline Sesudah evaluasi & 0,960 & 0,971 & 0,894 \\
\hline Niat & 0,945 & 0,950 & 0,517 \\
\hline Sikap & 0,807 & 0,962 & 0,514 \\
\hline Norma Subjektif & 0,838 & 0,522 \\
\hline Kontrol Perilaku & 0,938 &
\end{tabular}

Sumber: Analisis Data Primer 2018

Uji reliabilitas pada penelitian ini dilihat dari nilai composite reliability. Berdasarkan hasil analisis diketahui bahwa semua memiliki nilai reliabilitas komposit lebih dari 0,7. Interpretasi reliabilitas komposit sama seperti interpretasi untu cronbach alpha . Nilai reliabilitas komposit lebih dari 0,7 menunjukkan bahwa konstruk dalam model dapat dikatakan reliabel (akurat, konsisten, dan handal). Nilai composite reliability dan cronbach alpha disajikan pada tabel 5 dan gambar dua merupakan diagram jalur penelitian yang telah memenuhi syarat nilai loading factor. Berdasarkan gambar tiga diketahui nilai koefisien masing masing jalur sehingga dapat dilakukan konversi diagram jalur ke persamaan struktural penelitian. Hubungan antara sikap, norma subjektif, dan kontrol perilaku dengan niat untuk mengadopsi usahatani sayuran organik dapat dinyatakan dalam persamaan $\eta=0,061 \xi_{1}+$ $0,185 \xi_{2}+0,658 \xi_{3}+\zeta$ 


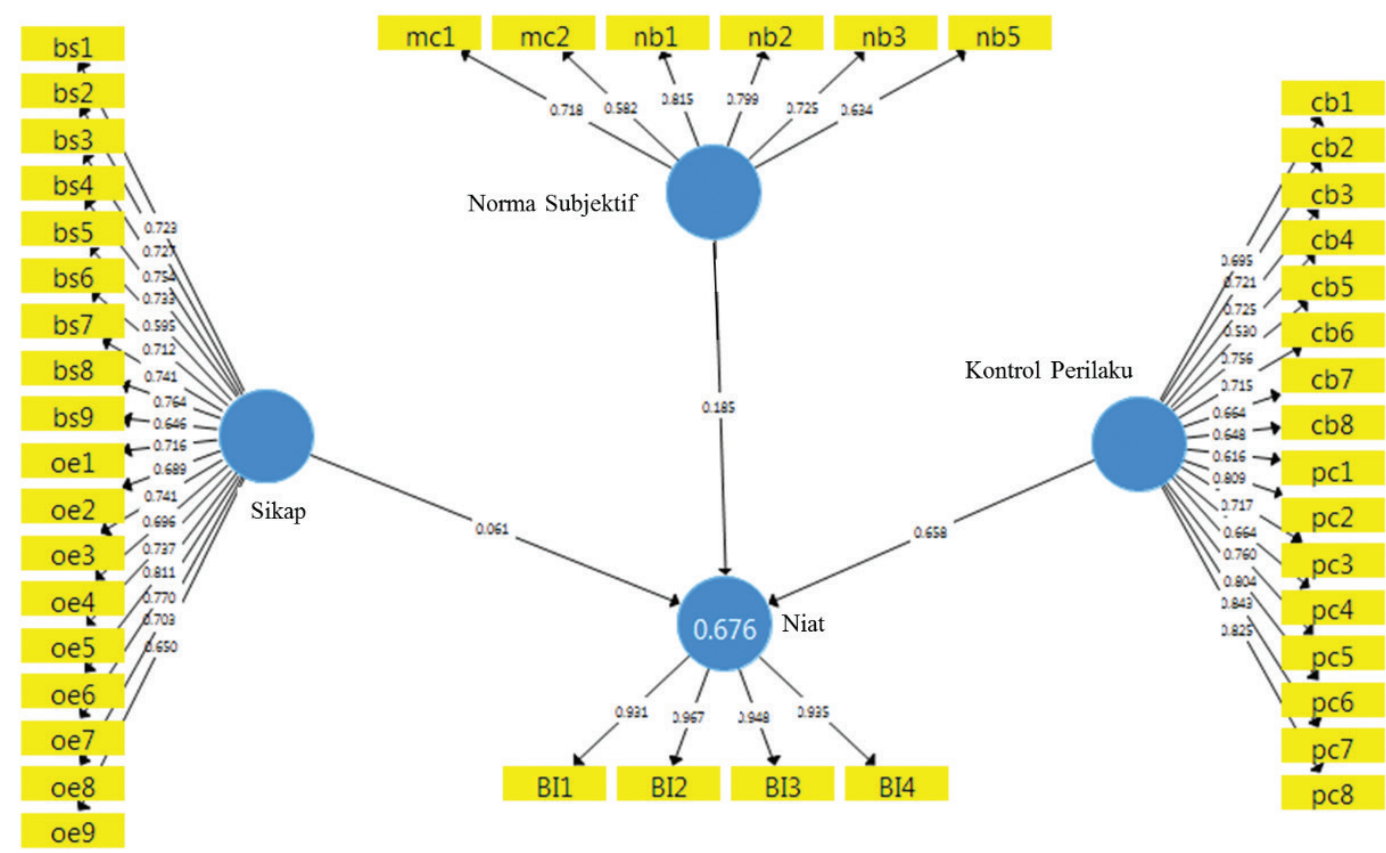

Gambar 3

Hasil Evaluasi Diagram Jalur Penelitian

Sumber: Analisis Data Primer 2018

Evaluasi model struktural diawali dengan melihat nilai $R$-Square dari variabel laten endogen. Nilai $R$-Square menunjukkan besarnya pengaruh variabel laten eksogen sikap, norma subjektifl, dan kontrol perilaku terhadap variabel laten endogen niat petani untuk mengadopsi usahatani sayuran organik (dapat dilihat pada gambar tiga). Nilai $R$-Square variabel laten endogen dalam penelitian ini sebesar 0,676 dapat diinterpretasikan bahwa variabilitas konstruk niat petani untuk mengadopsi usahatani sayuran organik dapat dijelaskan oleh variabilitas konstruk sikap, norma subjektif, dan kontrol perilaku sebesar $67,6 \%$, sedangkan $32,4 \%$ dijelaskan oleh variabel lain yang tidak dimasukkan dalam model penelitian. (Hair, 2014)by Hair, Hult, Ringle, and Sarstedt, provides a concise yet very practical guide to understanding and using PLS structural equation modeling (PLS-SEM menjelaskan nilai $R$-Square 0,$75 ; 0,5$; dan 0,25 masing masing dapat dikategorikan bahwa model kuat, moderat, dan lemah, sehingga $R$-Square niat untuk mengadopsi usahatani sayuran organik memilki R-Square yang moderat. $Q$-Square juga bertujuan untuk melihat kekuatan model penelitian yang dilihat dari prediktornya. Berdasarkan perhitungan $Q$ Square diketahui nilainya sebesar 0.676 di mana nilai tersebut lebih dari 0,35 sehingga model yang digunakan dalam penelitian ini dapat dikatakan kuat.

Goodness of fit merupakan evaluasi model struktural ketiga yang digunakan dalam penelitian ini. Tujuannya sama dengan uji uji sebelumnya yaitu untuk mengetahui kekuatan dari model penelitian yang digunakan. Perhitungan nilai GoF dengan menggunakan data nilai AVE dan $R$-Square dari variabel laten niat (BI) yaitu 0,894 dan 0,676 menggunakan rumus berikut GoF intensi $=\sqrt{A V E \times R \text { Square }}$. Perhitungan nilai GoF untuk melihat pengaruh semua variabel laten eksogen terhada variabel laten endogen niat. Berdasarkan perhitungan di atas diketahui nilai GoF niat untuk mengadopsi usahatani sayuran organik sebesar 0,772. Berdasarkan dengan kriteria penilaian GoF yaitu jika nilainya 0,10 menunjukkan model lemah, 0,25 menunjukkan model moderate, jika 0,36 bernilai kuat maka nilai GoF untuk niat masuk dalam kriteria yang kuat. 
Tabel 6

Nilai F-Square

\begin{tabular}{llll}
\hline \multicolumn{1}{c}{ Jalur } & & F-Square & \multicolumn{1}{c}{ Kriteria } \\
\hline Sikap $=>$ niat & 0,005 & Lemah \\
Norma Subjektif $=>$ niat & 0,070 & Lemah \\
Kontrol Perilaku $=>$ niat & 0,557 & Kuat \\
\hline
\end{tabular}

Sumber: Analisis Data Primer 2018

Evaluasi model struktural PLS selanjutnya adalah uji F-Square. Adapun tujaun uji F-Square ini untuk melihat pengaruh prediktor terhadap variabel latennya. Hasil Uji F-Square penelitian disajikan dalam Tabel enam.

Adapun kriteria penilaian F-Square yaitu jika nilainya 0,2 dianggap lemah, 0,15 dianggap moderat, 0,35 dianggap kuat. Berdasarkan Tabel 5 diketahui bahwa kontrol perilaku merupakan prediktor yang pengaruhnya kuat terhadap niat untuk mengadopsi usahatani sayuran organik. Sedangkan prediktor sikap dan norma subjektif memiliki pengaruh lemah terhadap niat untuk mengadopsi usahatani sayuran organik.

\section{Pengaruh Sikap, Norma Subjektif, dan Kontrol Perilaku terhadap Niat Mengadopsi Usahtani Sayuran Organik}

Berdasarkan model SEM yang telah dibuat dan dianalisis menggunakan SmartPLS, dapat diketahui pengaruh dari masing-masing variabel. Besar pengaruh dari masing-masing variabel dan arah hubungan variabel ditunjukkan oleh nilai original sample. Signifikansi pengaruh dari masing-masing variabel ditunjukkan oleh nilai t-statistik lebih dari 1,96 dan probability value (p-value) kurang dari 0,05 atau lima persen. Tabel 7 menyajikan nilai koefisien jalur beserta nilai t-statistik masing-masing jalur.

Tabel 7

Hasil Uji Hipotesis

\begin{tabular}{llll}
\multicolumn{1}{c}{ Jalur } & \multicolumn{1}{c}{ Original Sample } & \multicolumn{1}{c}{ T Statistics } & \multicolumn{1}{c}{ P Values } \\
\hline Sikap -> Niat & $0,061^{\text {ns }}$ & 0,560 & 0,576 \\
Norma Subjektif -> Niat & $0,185^{* *}$ & 2,363 & 0,018 \\
Kontrol Perilaku -> Niat & $0,658^{\text {*** }}$ & 6,798 & 0,000 \\
\hline
\end{tabular}

Sumber: Analisis Data Primer 2018

Keterangan : *** Signifikan pada tingkat kesalahan $1 \% \quad$ **Signifikan pada tingkat kesalahan $5 \%$ * Signifikan pada tingkat kesalahan $10 \% \quad$ ns Tidak Signifikan

Berdasarkan hasil analisis pada tabel tujuh diketahui nilai t-statistik dari hubungan sikap terhadap niat sebesar 0,560 nilainya kurang dari nilai t-tabel pada tingkat kesalahan besar dari 5\%, dengan demikian hipotesis Ho gagal ditolak yang menyatakan bahwa sikap tidak berpengaruh terhadap niat petani untuk mengadopsi usahatani sayuran organik. Hasil ini juga diperkuat dengan nilai $f$-square sikap yang memiliki pengaruh lemah sebagai prediktor dari variabel laten niat adopsi.
Dapat ditafsirkan bahwa bagimanapun petani menyikapi dengan dasar keyakinan dan manfaat yang dirasakan, apakah mendukung atau tidak, suka atau tidak, setuju atau tidak, hal itu tidak akan mempengaruhi niat petani untuk mengadopsi usahatani sayuran organik.

Petani sebenarnya telah mengetahui bagaimana prinsip prinsip dari sistem pertanian organik. Beberapa indikasi yang memperkuat adalah ada pengaruh sosial yang telah mencoba menstimulasi petani di Desa Kopeng untuk 
berusahatani sayuran organik, beberapa petani sudah menerapakan usahatani sayuran organik secara swadaya seperti perusahaan SOM (Sayur Organik Merbabu) di Dusun Sidomukti. Bahkan Desa Batur sebelah Desa Kopeng juga sudah menerapkan usahatani sayuran organik dengan kelompok agribisnis Tranggulasi dan Bangkit Merbabu. Namun sikap mereka tidak menyebabkan mereka secara langsung untuk berniat mengusahakan usahatani organik. Sedangkan perilaku/tindakan terbentuk dari niat itu sendiri.

Petani di Desa Kopeng memang sudah meyakini manfaat dan kemudahan yang didapatkan dari usahatani pertanian organik, sehingga menyikapi positif kemudahan yang diberikan jika berusahatani organik. Manfaat yang diperoleh seperti rata-rata biaya produksi yang lebih kecil, harga jual yang tinggi, kesuburan tanah meningkat, produk sayuran yang sehat dan ramah lingkungan. Namun dari keyakinan dan sikap itu belum menguatkan niat petani untuk mengkonversi ke usahatani sayuran organik baik secara bertahap maupun radikal. Petani terjebak dengan perilaku budidaya pertanian konvensional yang mengharuskan untuk menggunakan fungsi produksi dari paket revolusi hijau. Input produksi seperti pupuk kimia, pestisida, insektisida yang mengandung unsur kimia pengeksploitasi alam. Pada awal kemajuan teknologi ini memang memberikan kepastian akan hasil panen yang menguntungkan. Akhirnya petani menganggap sulit untuk meninggalkan kebiasaan yang telah terbangun bertahun-tahun. Bahkan petani menjadi ketergantungan akan pupuk kimia karena tanah sebagai media tanam tidak mampu menghasilkan unsur hara yang cukup secara alami lagi. Akibatnya tanah perlu waktu yang lama untuk recovery menjadi alami kembali. Hal ini berimbas juga pada ketergantungan petani pada biaya produksi yang dikendalikan oleh supplier input pertanian, sehingga petani sulit lepas dari ketergantungan ini.

Hattam (2006)enhance productivity and improve incomes. Nevertheless, adoption has been slow. The economics literature suggests profitability is the main constraint; however, the sustainable agriculture literature is inconclusive and considers attitudes of significant importance. As ecological behaviour is susceptible to a wide range of influences beyond an individual's control, environmental attitude alone is often a poor predictor of behaviour (Kaiser et al., 1999 juga menjelaskan hal senada bahwa sikap petani belum mampu mempengaruhi agar mengadopsi usahatani sayuran organik. Kesadaran petani akan prinsip pertanian berkelanjutan masih terhalang oleh motif kebiasaan dan faktor ekonomi. Kebiasaan diartikan sebagai aktivitas pertanian yang sudah rutin dilakukan dari generasi sebelumnya menerapkan sistem usahatani yang konvensional. Selain itu, faktor ekonomi yang menuntut kepastian hasil yang didapatkan dari aktivitas sebelumnya menunda niat petani untuk mengadopsi usahatani sayuran organik. Sikap yang diyakini disini sebagian merupakan konsekuensi dari 'respon yang dapat diterima secara sosial'. Individu mungkin menyadari atribut positif pertanian organik, seperti potensi perlindungan lingkungan, dan karenanya dapat merespons bahwa produksi organik baik karena kesadaran sosial menentukan hal ini penting. Akan tetapi, komponen pertanyaan yang digunakan untuk mengukur konstruk sikap termasuk manfaat produksi organik pada kesehatan keluarga, manfaat bagi lingkungan dan kenaikan harga jual produk. Ini adalah poin promosi utama yang digunakan untuk mendorong petani konvensional untuk beralih ke produksi organik dan merupakan alasan utama yang diberikan oleh produsen organik untuk mengadopsi metode organik. Hasil ini memberikan bukti jelas bahwa sikap positif saja tidak cukup untuk mendorong adopsi.

Berdasarkan hasil analisis pada Tabel tujuh diketahui t-statistik variabel norma subjektif sebesar 2,363 >1,96 nilai $t$ tabel yang menunjukkan nilai signifikan pada tingkat kesalahan 5\%. Dengan demikian hipotesis Ha gagal ditolak yang menyatakan bahwa norma subjektif/dukungan sosial berpengaruh terhadap niat petani mengadopsi usahatani sayuran organik. Hipotesis pengaruh norma subjektif terhadap niat yang dibangun pada penelitian ini diterima sesuai dengan hasil 
signifikansi. Pengaruh norma subjektif sebesar 0,185 menunjukkan pengaruh yang yang positif terhadap niat mengadopsi usahatani sayuran organik. Artinya, meningkatnya dukungan sosial yang menganjurkan petani untuk berusahatani sayuran organik akan meningkatkan niat petani untuk mengadopsi usahatani sayuran organik.

Temuan dari penelitian ini menunjukkan bahwa sumber pengaruh sosial yang menganjurkan untuk berusahatani sayuran organik lebih didominasi dari pemodal/ pebisnis, rekan sesama petani yang telah mencoba usahatani organik, dan dukungan pemerintah. Motif konsolidasi dari lingkungan sosial kepada petani berupa kemitraan agribisnis dengan pebisnis, anjuran dari rekan kelompok tani dan dukungan dari pemerintah. Pelaku bisnis organik menyadari bahwa Desa Kopeng memiliki potensi strategis bahwa desa ini dapat dikembangkan ke arah organik. Beberapa kelompok tani diasosiasikan untuk merencanakan bisnis dengan menerapkan greenhouse untuk mengurangi dampak hama dan penyakit tanaman dan udara yang tercemar pestisida. Diperlukan lebih banyak pelaku bisnis organik untuk lebih meningkatkan pengaruh norma subjektif untuk menstimulasi petani agar mengadopsi usahtani sayuran organik. Selain itu bahwa petani cenderung memiliki kepercayaan besar pada informasi berbasis pengalaman yang diberikan oleh petani organik yang sukses. Peran pedagang besar dan eksportir dengan minat pada sayuran organik juga dapat memotivasi petani untuk memulai proses konversi dengan menawarkan kontrak jangka panjang (Issa and Hamm, 2017the organic sector in Syria is comparatively young and only a very small area of FFV is organically managed. To date, little is known about Syrian farmers' attitudes towards organic FFV production. Therefore, the aim of this study was to explore the intentions and attitudes of Syrian farmers of FFV towards organic farming and how likely they are to convert their farms to organic production within the next five years. Using a two-stage cluster sampling procedure, 266 conventional farmers of FFV in 75 villages located in different districts of Syria's coastal region were selected for this survey. Data was collected through face-to-face interviews by a project partner in Syria (Citrus Fruit Board in Tartous). Sementara itu dukungan pemerintah berada pada level yang masih rendah dalam konsistensi program organik. Pelatihan dan sosialisasi program organik hanya sebatas menuntaskan masa program sehingga petani banyak menyarankan agar mereka didampingi dalam praktek pertanian organik. Hal ini sesuai dengan temuan penilitian tentang hubungan norma subjektif terhadap niat, di mana organisasi seperti asosiasi produsen dan lembaga pemerintah juga dapat mempengaruhi niat untuk mengadopsi metode organik.

Pada penelitian ini, pendapat dari lingkungan sosial bisa memberikan potensi untuk meningkatkan niat petani mengadopsi usahatani sayuran organik. Petani membuat keputusan setelah merasakan bahwa diperlukan adanya perbaikan untuk usahatani, dan perbaikan tersebut harus merupakan perbaikan yang menyeluruh. Wiratmaja (2017) menjelaskan bahwa opini subjektif dari seseorang dibutuhkan sebagai motivasi untuk menerima pertanian organik ataupun untuk menolak pertanian organik. Petani menyatakan bahwa lingkungan sosial memberikan informasi-informasi dan pandangan mengenai pertanian sayuran organik. Petani menggunakan pertanian organik karena lingkungan sosial berpendapat bahwa pertanian organik baik untuk digunakan petani tersebut.

Berdasarkan hasil analisis pada Tabel tujuh diketahui t-statistik kontrol perilaku sebesar 6,798 menunjukkan nilai yang signifikan pada tingkat kesalahan $1 \%$. Dengan demikian kontrol perilaku berpengaruh terhadap niat petani mengadopsi usahatani sayuran organik. Pengaruh kontrol perilaku sebesar 0,658 menunjukkan pengaruh yang positif terhadap niat mengadopsi usahatani sayuran organik. Artinya, meningkatnya kontrol perilaku atau kemampuan petani yang dimiliki petani untuk berusahatani sayuran organik akan meningkatkan niat petani untuk mengadopsi usahatani sayuran organik.

Studi ini menunjukkan bahwa kemampuan yang dirasakan oleh petani 
untuk berhasil mengkonversi ke sayuran organik merupakan pengaruh penting pada pembentukan niat, dengan sebagian besar petani memiliki persepsi keyakinan kontrol yang rendah. Petani bekerja secara kolektif untuk memecahkan masalah tentang produksi hingga pemasaran. Pada umumnya petani minim dalam mendapatkan akses informasi mengenai pertanian organik, akses subsidi pemerintah, kemampuan untuk membayar sertifikasi. Akan tetapi, hal itu disadari sangat penting untuk memilki kesanggupan tersebut jika mengkonversi usahatani sayuran organik. Jika petani memiliki sumberdaya dan kesanggupan untuk mengontrol usahatani organik ini, maka niat petani akan terbentuk lebih kuat. Konstruk kontrol perilaku yang dipersepsikan menekankan pada persepsi tentang biaya sertifikasi dan pengetahuan tentang metode produksi organik, kendala pada akses pembiayaan produksi melalui kredit dan kelangkaan informasi yang merupakan hambatan utama untuk adopsi.

Temuan dari penelitian ini memberikan temuan yang berbeda, Pertama hambatan petani untuk mengadopsi usahatani sayuran organik dipengaruhi oleh persepsi mereka apakah memiliki akses untuk mendapatkan informasi pembelajaran untuk menerapkan usahatani sayuran organik. Kedua, jika petani mempunyai sumberdaya yang dibutuhkan untuk syarat usahatani sayuran organik, niat petani akan menguat. Kemudian, seorang petani yang merasa bahwa usahatani sayuran organik dapat diterapkan dengan menggunakan pengetahuan dan keterampilannya yang ada, kemungkinan besar ia akan menerima untuk diadopsi.

Sementara, kondisi akses sumberdaya ternyata menjadi faktor signifikan lain yang mempengaruhi niat petani. Hasil ini menunjukkan dampak, Pertama, petani kemungkinan mengadopsi usahatani sayuran organik ketika mereka yakin memilki cukup sumberdaya lahan untuk mendukung adopsi pertanian organik, Kedua, jika petani meyakini bahwa sarana pendukung (sertifikasi, akses kredit, dan subsidi pemerintah) yang tepat tidak sulit ditemukan, mereka menjadi lebih mudah berniat mengadopsi. Ketiga, keputusan petani untuk berusahatani sayuran organik juga ditentukan oleh kemampuan petani, apakah metode tersebut itu terjangkau atau tidak.

\section{SIMPULAN}

Penelitian ini menunjukkan bahwa niat untuk mengadopsi usahatani sayuran organik lebih ditentukan oleh faktor yaitu kontrol perilaku yang dirasakan dan norma subjektif. Sementara itu faktor niat keinginan untuk memilih usahatani sayuran organik tidak cukup berpengaruh dalam tindakan mengubah pilihan. Perspektif penelitian ini berusaha memberikan sudut pandang baru bahwa manajemen perubahan perlu mempertimbangkan faktor yang mempengaruhi niat berperilaku. Kontrol perilaku yang dirasakan petani menjadi perhatian penting bagi stakeholder maupun pengembang bisnis organik. Tahapan selanjutnya yang perlu didukung adalah kekuatan kontrol berupa bertambah kuatnya kemampuan dan sumberdaya yang dimiliki untuk meningkatkan niat mengadopsi usahatani sayuran organik sehingga niat petani dapat menguat dan menjadi sebuah perilaku berusahatani sayuran organik. Meskipun petani Desa Kopeng memiliki niat positif, tetapi masih dalam kategori cukup baik untuk beralih ke pertanian organik, inisiatif pelaku bisnis, lembaga pemerintah, LSM dan lembaga pembangunan internasional tentang pertanian organik penting untuk menyebarkan informasi lebih lanjut tentang konversi, sertifikasi, dan persyaratan kualitas untuk produk organik. Inisiatif semacam itu juga harus diberi perhatian khusus agar informasi lebih lanjut tentang permintaan yang terus meningkat untuk produk organik segar di pasar regional dan internasional, bersama dengan meningkatkan persepsi petani dan kesadaran akan manfaat ekonomi, kesehatan, dan lingkungan dari memproduksi sayuran secara organik. Inisiatif ini tidak boleh mengabaikan atau meremehkan peran penting yang dapat dimainkan oleh petani sayuran organik yang sukses di wilayah lain dalam membantu dan memotivasi petani 
untuk mengonversi pertanian mereka menjadi produksi sayuran organik bersertifikat.

Petani cenderung memiliki menerima informasi berbasis pengalaman yang diberikan oleh petani organik yang sukses. Peran pedagang besar dan eksportir (pelaku bisnis) dengan minat pada sayuran organik juga dapat menentukan dalam memotivasi petani untuk memulai proses konversi dengan menawarkan kontrak jangka panjang. Developer agribisnis yang bergerak di sektor sayuran organik disarankan agar mempertimbangkan aspek kontrol perilaku petani dan merencanakan kemitraan agribisnis sayuran organik dengan petani setempat karena pelaku bisnis adalah salah satu faktor sosial yang berdampak pada keberlanjutan adopsi usahatani sayuran organik di Desa Kopeng.

\section{DAFTAR PUSTAKA}

Ajzen, Icek. 2005. "Attitudes, Personality and Behaviour." in Mapping Social Psychology.

Ayuya, Oscar I., Eric O. Gido, Hillary K. Bett, Job K. Lagat, Alexander K. Kahi, and Siegfried Bauer. 2015. "Effect of Certified Organic Production Systems on Poverty among Smallholder Farmers: Empirical Evidence from Kenya." World Development.

Borges, João Augusto Rossi, Alfons G. J. M. Oude Lansink, Claudio Marques Ribeiro, and Vanessa Lutke. 2014. “Understanding Farmers' Intention to Adopt Improved Natural Grassland Using the Theory of Planned Behavior." Livestock Science.

Cohen, Jacob. 1992. “Cohen (1992) - A Power Primer.Pdf." Psychological Bulletin.

F. Hair Jr, Joe, Marko Sarstedt, Lucas Hopkins, and Volker G. Kuppelwieser. 2014. "Partial Least Squares Structural Equation Modeling (PLS-SEM)." European Business Review.

Hattam, Caroline. 2006. "Adopting Organic Agriculture : An Investigation Using the Theory of Planned Behaviour." in Land Economy Research Group.

Icek Ajzen. 2005. "Ajzeni-2005-AttitudesPersonality-and-Behaviour-2ndEd-Open-University-Press.Pdf." International Journal of Strategic Innovative Marketing.

Issa, Irwa and Ulrich Hamm. 2017. "Adoption of Organic Farming as an Opportunity for Syrian Farmers of Fresh Fruit and Vegetables: An Application of the Theory of Planned Behaviour and Structural Equation Modelling." Sustainability (Switzerland).

Kuminoff, Nicolai V. and Ada Wossink. 2010. "Why Isn't More Us Farmland Organic?" Journal of Agricultural Economics.

Läpple, Doris. 2010. "Adoption and Abandonment of Organic Farming: An Empirical Investigation of the Irish Drystock Sector." Journal of Agricultural Economics.

Lapple, Doris and Hugh Kelley. 2010. "Understanding Farmers' Uptake of Organic Farming: An Application of the Theory of Planned Behaviour." The 84th Annual Conference of the Agricultural Economics Society.

Mayrowani, Henny. 2012. “The Development of Organic Agriculture in Indonesia."

Forum Penelitian Agro Ekonomi 30(2):91-108.

Pietola, K. S. 2001. “Farmer Response to Policies Promoting Organic Farming Technologies in Finland." European Review of Agriculture Economics.

Wiratmaja I.I., Nurjanah N., Kurniawati A. 2017. "Model Penerimaan Petani Terhadap Teknologi Sistem Pertanian Organik Di Kabupaten Tasikmalaya." Jurnal Manajemen Teknologi. 16(1):81-91. 